\section{Humberto Rosa'}

Marcelo Zubaran Goldani'

Thomas Scanlon"

\section{Antônio Augusto Moura da Silva"'}

\section{Elsa Justo Giugliani'}

Marilyn Agranonik'

\section{Andrew Tomkins"}

\section{Barriers for HIV testing during pregnancy in Southern Brazil}

\section{ABSTRACT}

OBJECTIVE: To assess HIV testing rate and determine risk factors for not have been tested during pregnancy.

METHODS: A cross-sectional study was carried out in Porto Alegre, Southern Brazil, from December 2000 to February 2001. Socioeconomic, maternal and healthcare variables were obtained by means of a standardized questionnaire. Crude and adjusted odds ratios and their $95 \%$ confidence intervals were obtained in logistic regression models.

RESULTS: A total of 1,642 mothers were interviewed. Of them, 94.3\% reported being offered HIV testing before or during pregnancy or during labor; 89 mothers $(5.4 \%)$ were not tested or did not know if they were tested. Attending fewer than six prenatal visits, being single and younger than 18 years old were relevant barriers preventing HIV testing. There was found a relationship between maternal schooling and the category of prenatal care provider. Having low 22.20 (12.43-39.67) or high 3.38 (1.86-7.68). schooling and being cared in the private sector strongly reduced the likelihood of being HIV tested.

CONCLUSIONS: The Brazilian Health Ministry's recommendation for universal counseling and HIV testing has been successfully implemented in the public sector. In order to improve HIV testing coverage, new strategies need to target women cared in the private sector especially those of low schooling.

KEYWO RDS: HIV. Pregnancy. HIV antibodies. Prenatal care. HIV infections, diagnosis.

\section{RESU MO}

Faculdade de Medicina. Universidade

Federal do Rio Grande do Sul. Porto

Alegre, RS, Brasil

" Centre for International Child Health. Institute of Child $\mathrm{Health}$. University

College of London. London, UK

II' Departamento de Saúde Pública. Universidade Federal do Maranhão. São Luís, MA, Brasil

\section{Correspondence:}

Marcelo Zubaran Goldani

Rua André Puente, 200 Apto. 501

90035-003 Porto Alegre, RS, Brasil

E-mail: mgoldani@hcpa.ufrgs.br

Received: 12/8/2005. Approved: 12/20/2005.
OBJETIVO: Avaliar o padrão de realização do teste para a detecção do HIV e os fatores de risco para a sua não realização durante a gestação.

MÉTODOS: Trata-se de um estudo transversal realizado em Porto Alegre, de dezembro de 2000 a fevereiro de 2001. Foram obtidas de puérperas variáveis biológicas, demográficas e sociais por meio de questionário padronizado. Foi elaborado modelo de regressão logística para determinar os fatores risco para não ser testada para a detecção do HIV.

RESULTADOS: Foram entrevistadas 1.642 mães. Destas, 94,3\% informaram testadas para o HIV. Oitenta e nove $(5,4 \%)$ não foram testadas para HIV ou não sabiam se haviam feito o teste. Realizar menos do que seis consultas pré-natais, ausência de companheiro e idade inferior a 18 anos foram fatores de risco para não realização do teste. Houve interação entre escolaridade materna e categoria do atendimento pré- 
natal. Baixa escolaridade 22,20 (12,43-39,67) e alta escolaridade 3,38 (1,86-7,68) com acompanhamento pré-natal no setor privado foram condições preponderantes para não realização do teste de detecção do HIV.

CONCLUSÕES: A testagem universal para a detecção do HIV durante o pré-natal no setor público foi implementada com sucesso pelo Ministério da Saúde. Contudo, novas intervenções e estratégias necessitam ser direcionadas objetivando ampliar o acesso ao diagnóstico da infecção por HIV no setor privado.

\section{DESCRITO RES: HIV. G ravidez. Anticorpos anti-HIV. Cuidado pré-natal. Infecções por HIV, diagnóstico.}

\section{INTRODUCTION}

In Brazil, universal voluntary HIV testing has been available for all pregnant women since 1997. Free anti-retroviral therapy is available for all HIV-positive pregnant women from week 14 of pregnancy up to delivery and for their newborns. In order to provide an adequate replacement for breastfeeding, infant formula preparations are available during the first six months of life at no cost.*** The program has had an extremely significant impact in terms of lowering mother-to-child HIV transmission, with a decrease from 926 HIV-infected newborns in 1996 to 111 in $2001 .^{3}$

Some studies have estimated the coverage of HIV testing among pregnant women in Brazil. One study ${ }^{13}$ was carried out before free anti-retroviral therapy was available for all pregnant women and showed an overall HIV testing rate of $68 \%$ during prenatal care in the city of Ribeirão Preto (State of São Paulo). Recently, after free access to anti-retroviral therapy, another study showed similar results. The coverage of HIV testing during pregnancy was 52\% nationwide, $69 \%$ in the Southeast and $72 \%$ in the Southern region. ${ }^{17}$

Current research suggests that mothers who are HIV infection diagnosed late in the course of their pregnancies or after delivery come from poor socioeconomic background. ${ }^{20}$ The reasons why these women are not being tested when anti-retroviral therapy is available are not clear.

The present study sought to determine the coverage of HIV testing and to identify barriers that reduce the likelihood of HIV testing during pregnancy. The study findings will contribute to promoting changes in practice and policy in order to improve HIV testing rate and anti-retroviral therapy coverage. This is particularly relevant given there are resources available to address health care needs of HIV infected women and their children.

\section{METHODS}

A cross-sectional hospital-based study was carried out in the city of Porto Alegre, Southern Brazil, from December 2000 to February 2001. There were 1,440,000 inhabitants in Porto Alegre in 1999.

All mothers who gave birth in the city's three largest public hospitals during the study period were eligible, making it a total of 1,658 mothers. These three hospitals accounted for $9,570(41 \%)$ of 23,360 deliveries reported in the city in 2000 . Hospital deliveries corresponded to $99 \%$ of all live births in the city. It was estimated that a sample size of 1,268 subjects would provide an odds ratio of 1.80 with $95 \%$ confidence interval and $80 \%$ power, considering a $10 \%$ prevalence of not being HIV tested in the unexposed group. ${ }^{6}$

Socioeconomic, maternal and medical care information were obtained from the mothers by means of a standardized questionnaire. Interviews were performed after delivery by trained personnel supervised by the research team. The socioeconomic variables were: marital status, educational level; and the category of prenatal care provider. Maternal variables were: mother's age and number of pregnancies including the current one. The medical care variables were: the pregnancy trimester in which the first prenatal visit occurred, and number of prenatal care visits.

A small amount of additional data was collected from prenatal care records in order to confirm whether HIV testing was performed. Less than $1 \%$ of the mothers refused to be interviewed, and data were missing for some mothers.

HIV testing during pregnancy care was considered 
Table 1 - Anti-HIV antibody testing and prevalence of HIV-positive women during pregnancy. Porto Alegre, Brazil, 2001.

\begin{tabular}{lcccc}
\hline Anti-HIV antibody testing & Women tested $(\mathrm{N})$ & $(\%)$ & $95 \% \mathrm{Cl}$ & $\mathrm{HIV}$-positive women \\
\hline First trimester & 539 & 32.8 & $30.5-35.2$ & 4 \\
Second trimester & 723 & 44.0 & $41.6-46.5$ & 8 \\
Third trimester & 219 & 13.3 & $11.7-15.1$ & 3 \\
Rapid test during labor & 48 & 2.9 & $2.2-3.9$ & 5 \\
Before pregnancy & 20 & 1.2 & $0.7-1.9$ & 0 \\
Do not know if they were tested & 68 & 4.1 & $3.2-5.2$ & 0 \\
Not tested & 21 & 1.3 & $0.8-1.9$ & - \\
Declined to be tested after counseling & 4 & 0.2 & $0.1-0.6$ & - \\
\hline Total & 1,642 & 100 & & 20 \\
\hline
\end{tabular}

as the dependent variable, and coded 0 if tested and 1 if not tested. Mothers $(n=16 ; 1 \%)$ known to be HIV-positive before the current pregnancy were excluded from the analysis. Thus, the sample comprised 1,642 parturient women. Pregnant women who did not know if they were HIV tested or who were not tested at all were defined as "not being HIV tested". To investigate the associations, crude and adjusted odds ratios and their $95 \%$ confidence intervals were estimated in logistic regression models. P-values for each variable were derived from the log-likelihood ratio statistic. A conceptual model guided the regression strategy used in the adjusted analysis. ${ }^{21}$ According to this approach, socioeconomic variables are the first events that directly or indirectly should determine the outcome. For this reason, the first model was adjusted only for socioeconomic variables. The second model included these socioeconomic variables plus maternal variables. The third model was adjusted for socioeconomic and maternal variables plus medical care variables. Gestational age was included in the last model as a continuous variable and was measured in complete weeks according to Capurro's method. ${ }^{4}$ The odds ratios reported for socioeconomic variables were drawn from model 1 , those for maternal variables were drawn from model 2 and those for health care variables were drawn from the estimates derived in model 3.

Plausible interactions were tested. There was an interaction between maternal schooling and the category of prenatal care provider. To better explain this interaction a new variable including maternal schooling and category of prenatal care provider together was presented in four categories as follows: low schooling mothers cared in the public sector, low schooling mothers cared in the private sector, high schooling mothers cared in the public sector and high schooling mothers cared in the private sector. Low schooling mothers cared in the public sector were taken as reference.

Consent and ethical approval for the study were obtained from the Ethics Committees of all three hospitals. Consent was obtained individually from each mother who participated in the study.

\section{RESU LTS}

A total of 1,553 women (94.6\%) reported being offered HIV testing during their current pregnancy, of which $1,549(94.3 \%)$ were HIV tested shortly before or during their current pregnancy. Four $(0.2 \%)$ declined to be tested after counseling. Eighty-nine (5.4\%) were not HIV tested during their current pregnancy and 48 were tested with rapid testing during labor. Forty-one were not either offered voluntary counseling or testing during their current pregnancy, including 20 who were only tested before their current pregnancy (Table 1).

The majority of women were tested in the first and second trimesters of pregnancy. Eight women were diagnosed as HIV-positive late in the second trimester, corresponding to $40 \%$ of the all HIV-positive women diagnosed in the current pregnancy (Table 1). The group of women tested by rapid test just before delivery showed the highest percentage of HIV-posi-

Table 2 - Social, maternal and medical care variables of women attending prenatal care. Porto Alegre, Brazil, 2001.

\begin{tabular}{lcc}
\hline Variable & $\mathrm{N}$ & $\%$ \\
\hline Marital status & & \\
M arried & 1,475 & 90.1 \\
Single & 158 & 9.7 \\
M issing data & 5 & 0.3 \\
Maternal schooling & 923 & 56.4 \\
Low & 713 & 43.5 \\
High & 2 & 0.1 \\
Missing data & 1,401 & 85.5 \\
Category of prenatal care provider & 237 & 14.5 \\
Public & & \\
Private & 1,088 & 66.4 \\
Maternal age (years) & 357 & 21.8 \\
18-30 & 192 & 11.7 \\
$31-44$ & 1 & 0.1 \\
<18 & 545 & 33.3 \\
Missing data & 688 & 42.0 \\
Number of pregnancies & 405 & 24.7 \\
>3 & & \\
$2-3$ & 1,445 & 88.2 \\
1 & 106 & 6.5 \\
Trimester of first prenatal care visit & 87 & 5.3 \\
First or second & & \\
Third & 1,040 & 63.5 \\
Missing data & 497 & 30.3 \\
Number of prenatal care visits & 101 & 6.2 \\
>5 & 1,638 & 100.0 \\
\hline 5 & & \\
Missing data & & \\
\hline Total & &
\end{tabular}


Table 3 - Unadjusted analysis of social, maternal and medical care risk factors for not being HIV tested during pregnancy. Porto Alegre, Brazil, 2001.

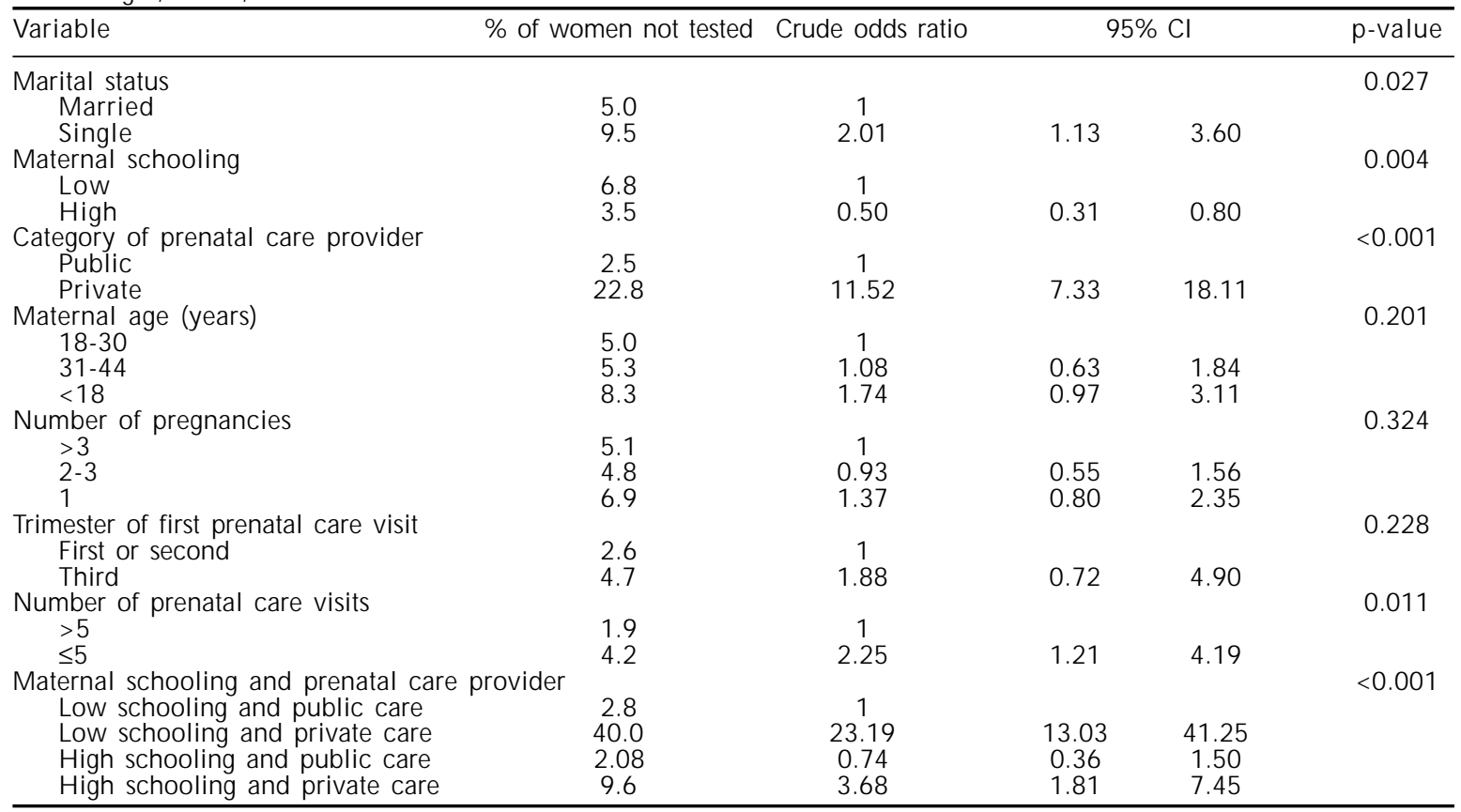

tive results. The overall prevalence of positive HIV testing (including women who were tested by rapid test) was $1.2 \%$ (95\% CI: 0.1-1.9).

Table 2 shows the independent variables included in the analysis. Mothers were predominantly married (90.1\%), and most of them had low schooling (56.4\%). Most attended prenatal care in the public sector $(85.5 \%)$ and were between 18 and 30 years of age $(66.4 \%), 42.0 \%$ had had two to three pregnancies, most began prenatal care in the first or second trimester of pregnancy $(88.2 \%)$ and attended more than five prenatal care visits $(63.5 \%)$.

Those with an increased likelihood of not being HIV tested in the unadjusted analysis were single, attended prenatal care in the private sector and had less than six prenatal visits. In contrast, mothers with high schooling were at a low risk of not being tested (Table 3). Among 237 women (14.5\%) who attended prenatal care in the private sector, four were diagnosed as HIVpositive, a prevalence of $1.7 \%$ (95\% CI: 0.1-4.2).

In the adjusted analysis, being younger than 18 years and attending fewer than six prenatal care visits were risk factors for not being HIV tested. Living without a partner was marginally associated with an increased risk of not being HIV tested ( $p$-value between 0.05 and 0.10 ). There was an interaction between maternal schooling and the category of prenatal care provider. Mothers with low schooling who were cared in the private sector had the highest risk of not being HIV tested (OR=22.2), whereas mothers with high schooling who were cared in the private sector had 3.78 higher chance of not being HIV tested (Table 4).

\section{DISCUSSION}

Despite the high rate of HIV testing during pregnancy, some barriers for testing were identified, such as those related to medical care. Having low schooling and being cared in the private sector were most strongly associated with reduced likelihood of being HIV tested. Having high schooling and being cared in the private sector also increased the risk of not being HIV tested. Attending fewer than six prenatal visits, being single and young ( $<18$ years) were also relevant barriers preventing HIV testing.

Despite almost universal availability of HIV testing, socioeconomic inequalities are still preventing women from poor backgrounds from testing, especially if they are cared in the private sector. The study results showed that the private sector is not adequately implementing the policy of universal HIV testing offer: $22.8 \%$ of mothers cared in this sector were not tested and refusal rate was only $0.2 \%$. Conversely, for those cared in the public sector HIV testing coverage is almost universal (only $2.5 \%$ were not tested).

The results add to the evidence that the Brazilian Ministry of Health has nearly overcome two major obstacles to the systematic voluntary HIV testing of 
Table 4 - Adjusted models of social, maternal and medical care risk factors for not being HIV tested during pregnancy. Porto Alegre, Brazil, 2001.

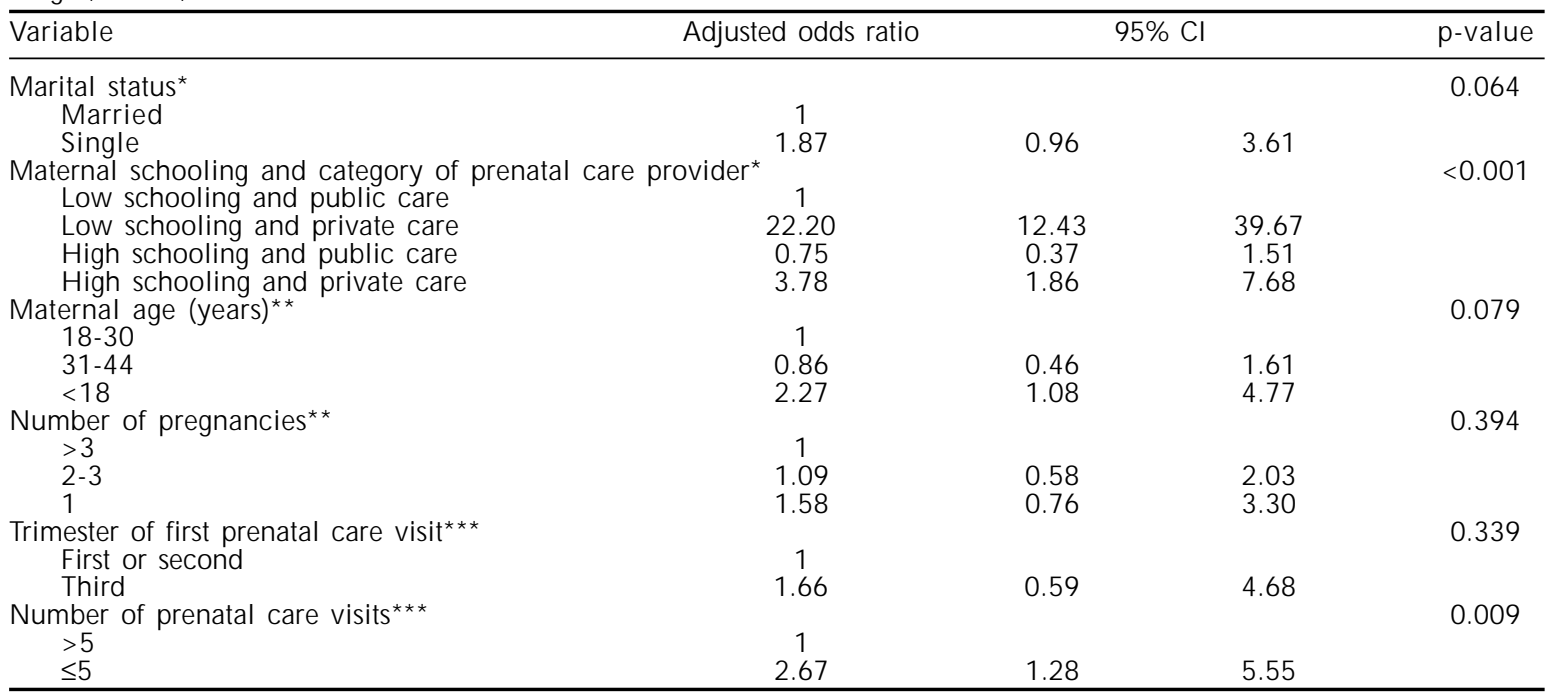

*Model 1: adjusted for socioeconomic variables: marital status, maternal schooling and category of prenatal care provider **Model 2: adjusted for maternal variables: maternal age and number of pregnancies plus variables in model 1

***M odel 3: adjusted for medical care variables: trimester of first prenatal care visit and number of prenatal care visits plus variables in model 2 and also adjusted for gestational age in completed weeks

pregnant women seen in developing countries: cost, and the complex logistics of testing and treating with zidovudine. Considering that only four mothers refused to be tested after the counseling session, the acceptance rate was similar to that found in Thailand, Sweden and Canada ${ }^{2,10,23}$ and higher than the rate observed in England and the United States (74\% and $95 \%$, respectively). ${ }^{7,9}$

The estimated prevalence of HIV-positive testing in pregnant women in Brazil was $0.6 \%$, which ranks Brazil in an intermediate position between high-rate African countries and low-rate developed countries. ${ }^{11,15,18,22}$ Porto Alegre showed a similar prevalence when compared with other large cities in Brazil: $1.5 \%$ in Rio de Janeiro, ${ }^{14}$ and $0.8 \%$ in Vitória. ${ }^{12}$

Despite the high HIV testing rate in the first and second trimesters, a large number of HIV-positive women were still diagnosed late in the third trimester. This finding highlights the importance of rapid HIV testing as a complementary strategy for increasing HIV testing and diagnosis, although a later diagnosis can constitute an additional risk for motherto-child transmission. ${ }^{8}$ However, the use of rapid HIV testing has a limitation because it can produce false positive results. ${ }^{24}$

The finding of high risk of not being tested for mothers cared in the private sector was unexpected. Doc- tors may regard better-off women as being less exposed to the risk of HIV infection. It can also be speculated that doctors may also fear losing their patients if they offer HIV testing to them because this can be interpreted as suggestive of unsafe sexual behavior. ${ }^{16}$ The private sector provides approximately $30 \%$ of all prenatal care in Brazil,,$^{5}$ thus a policy aimed at increasing HIV testing in this sector could have a positive impact on the mother-to-child transmission rate.

Having an adequate number of prenatal care visits was associated with higher rates of HIV testing, therefore improving access to prenatal care and increasing the number of prenatal care visits appears to be a key factor for increasing HIV testing rates. ${ }^{1,6,19}$

The present study showed that the Brazilian Health Ministry's recommendation for universal counseling and HIV testing has been successfully implemented in the public sector. However, those from socially underprivileged groups and who were cared in private sector had reduced chance of being HIV tested. Therefore, in order to improve HIV testing, new strategies need to target women cared in the private sector especially those of low schooling. In addition, women who attend few prenatal care visits, who are living without a partner and are younger than 18 years of age as well as those better-off women cared in the private sector need to be targeted as well. 


\section{REFEREN CES}

1. Almeida SDM, Barros MBA. Equidade e atenção à saúde da gestante em Campinas (SP), Brasil. Rev Panam Salud Pública. 2005;17(1):15-25.

2. Amornwichet $P$, Teeraratkul $A$, Simonds RJ, Naiwatanakul T, Chantharojwong $N$, Culnane $M$, et al. Preventing mother-to-child HIV transmission: the first year of Thailand's national program. JAMA. 2002;288(2):245-8.

3. Ministério da Saúde. Boletim epidemiológico Aids; 2001.

4. Capurro H, Konichezky S, Fonseca O, CaldeyroBarcia R. A simplified method for diagnosis of gestational age in the newborn enfant. J Pediatr. 1978;93(1):120-2.

5. Goldani MZ, Giugliani ERJ, Scanlon T, Rosa H, Castilhos K, Feldens L, et al. Voluntary HIV counseling and testing during prenatal care in Brazil. Rev Saúde Pública. 2003;37(5):552-8

6. Goldani MZ, Barbieri MA, Silva AAM, Bettiol H. Trends in prenatal care use and low birth weight in southeast Brazil. Am J Public Health. 2004;94(8):1366-71.

7. Howard LC, Hawkins DA, Marwood R, Shanson DC, Gazzard BG. Transmission of immunodeficiency virus by heterosexual contact with reference to antenatal screening. Br J O bstet Gynaecol. 1989;96(2):136-9.

8. João EC, Cruz ML, Menezes JA, Matos HJ, Calvet GA, $D^{\prime}$ Ippolito $M M$, et al. Vertical transmission of HIV in Rio de Janeiro, Brazil. Aids. 2003;17(12):1853-5.

9. Lansky A, Jones JL, Frey RL, Lindegren ML. Trends in HIV among pregnant women: U nited States, 19941999. Am J Public Health. 2001;91(8):1291-3.

10. Larsson G, Spangberg L, Lindgren $S$, Bohlin $A B$ Screening for HIV in pregnant women: a study of maternal opinion. AIDS Care. 1990;2(3):233-8.

11. Menegon T, Baldo V, Cristofoletti M, Grella P, Carletti $M$, Trivello R. Seroprevalence of HIV infection among pregnant women in Veneto region (north-east Italy). Public Health. 2000;114(6):477-9.

12. Miranda $A E$, Alves $M C$, N eto $R L$, Areal $K R$, Gerbase $A L$. Seroprevalence of HIV, hepatitis B virus, and syphilis in women at their first visit to public antenatal clinics in Vitória, Brazil. Sex Transm Dis. 2001;28(12):710-3.
13. Neves FR, Passos AD, Gueleri WL. Disponibilidade de sorologia anti-HIV como teste voluntário na rotina do atendimento pré-natal em unidades básicas de saúde. Rev Saúde Pública. 1999;33(6):624-5.

14. Nogueira $S A$, Lambert JS, Albuquerque $A L$, Rodrigues $\mathrm{R}$, Reis $\mathrm{S}$, Bornia $\mathrm{R}$, et al. Assessment of a rapid HIV strategy during labor: a pilot study from Rio de Janeiro, Brazil. J Hum Virol. 2001;4(5):278-82.

15. Ross EL, Morrison JC. Screening for human immunodeficiency virus infection during pregnancy. Pediatr AIDS HIV Infected. 1997;8(1):12-4.

16. Royce RA, Walter EB, Fernandez MI, Wilson T, Ickovics JR, Simonds RJ, et al. Barriers to universal prenatal HIV testing in 4 US locations in 1997. Am J Public Health. 2001;91(5):727-33.

17. Souza Júnior PRB, Szwarcwald $C L$, Babosa Júnior $B$, Cavalho MF, Castilho EA. Infecção pelo HIV durante a gestação: estudo-sentinela parturiente, Brasil, 2002. Rev Saúde Pública. 2004;38(6):764-72.

18. Szwarcwald $C L$, Castilho EA. Estimativa do número de pessoas de 15 a 49 anos infectadas pelo HIV, Brasil, 1998. Cad Saúde Pública. 2000;16 Supl 1:135-41.

19. Tess BH, Rodrigues LC, Newell ML, Dunn DT, Lago TDG. Breastfeeding, genetic, obstetric and other risk factors associated with mother-to-child transmission of HIV-1 in São Paulo state, Brazil. Aids. 1998;12(5):513-20.

20. Vermelho LL, Barbosa RHS, Nogueira SA. Mulheres com aids: desvendando histórias de risco. Cad Saúde Pública. 1999;15(2):369-79.

21. Victora CG, Huttly SR, Fuchs SC, Olinto MT. The role of conceptual frameworks in epidemiological analysis: a hierarchical approach. Int J Epidemiol. 1997;26(1):224-7.

22. Villamor E, Msamanga G, Spiegelman D, Coley J, Hunter DJ, Peterson KE, et al. HIV status and sociodemographic correlates of maternal body size and wasting during the pregnancy. Eur J Clin Nutr. 2002;56(5):415-24.

23. Wang FL, Larke B, Gabos S, Hanrahan A, Schopflocher D. Potential factors that may affect acceptance of routine prenatal HIV testing. Can J Public Health. 2005;96(1):60-4.

24. Zacharias NM, Athanassaki ID, Sangi-Haghpeykar $\mathrm{H}, \mathrm{G}$ ardner MO. High false-positive rate of human immunodeficiency virus rapid serum screening in a predominantly hispanic prenatal population. J Perinatol. 2004;24(12):743-7. 